\title{
IbM Kelompok Masyarakat Pesisir Terhadap Perlindungan dan Pengelolaan Lingkungan Hidup di Desa Pria Laot Kota Sabang
}

\author{
Yusra ${ }^{1}$, Eliana ${ }^{2 *}$, Dahlan ${ }^{3}$ \\ 1,3 Program Studi Manajemen, Fakultas Ekonomi, Sekolah Tinggi Ilmu Ekonomi Sabang, Jalan \\ Peurada Utama Po Box 166, Kota Banda Aceh, Provinsi Aceh, Indonesia. \\ 2 Program Studi Akuntansi, Fakultas Ekonomi, Sekolah Tinggi Ilmu Ekonomi Sabang, Jalan \\ Peurada Utama Po Box 166, Kota Banda Aceh, Provinsi Aceh, Indonesia \\ Corresponding Email: eliana@stiesabang.ac.id 2.
}

Article History:
Received: Jan 19th 2021
Revised: Feb 14th 2021
Accepted: Apr 23th 2021

Keywords: Environmental Law Conscious; Mangrove Forest Conservation; Coastal Management Community Group.
Abstract: The purpose of this service is to provide solutions by implementing Science through the Science and Technology program for the community at the STIES Research and Community Service Center to carry out advocacy and legal consultation to the community in Batee Shok Juroeng Pria Laot Village, Sukakarya District, Sabang City in order to minimize conflict and grant authority. local communities in the protection and management of the environment, especially the management of resources in coastal areas. The method used in IbM activities with a social approach, implementing Legal Counseling and Program Strategies for Coastal Mangrove Forest Management Community Groups, activities carried out by Focus Group Discussion (FGD), and implementation involving students as part of learning in the ways and processes of resolving environmental disputes related to with a Subject in Environmental Law and Management Economics. The conclusions of the service activities are; 1) The establishment of environmental law awareness for coastal communities to maintain and protect coastal resources in residential areas, 2) Form and reorganize the Coastal Management Community Group, and 3) Open access for people outside Batee Shok Village to utilize supporting facilities and infrastructure. Sabang City National Park Tourism. 


\section{Pendahuluan}

Wilayah pesisir yang merupakan sumber daya potensial di Indonesia adalah suatu wilayah peralihan antara daratan dan lautan [1]. Sumber daya ini sangat besar yang didukung oleh adanya garis pantai sepajang sekitar $81.000 \mathrm{~km}[2,3]$. Garis pantai yang panjang ini menyimpan potensi kekayaan sumber alam yang besar [4,5]. Potensi itu diantaranya potensi hayati dan non hayati [6]. Potensi hayati misalnya; perikanan, hutan mangrove, dan terumbu karang, sedangkan potensi nonhayati misalnya; mineral dan bahan tambang serta pariwisata [6,7]. Di daerah ini juga berdiam para nelayan yang sebagian besar masih prasejahtera [8]. Keadaan pantai di Indonesia sangat bervariasi, yaitu mulai dari pantai pasir putih-berbatu, landai-terjal, bervegetasi-berlumpur, teduh, bergelombang yang semua ini sangat cocok dengan berbagai peruntukannya, seperti perikanan pantai, budidaya perikanan, industri perhotelan, turisme, dan lain-lain $[9,10$, $11]$.

Dengan demikian pengelolaan wilayah pesisir berbasis masyarakat adalah pendekatan pengelolaan yang melibatkan kerja sama antara masyarakat setempat dan pemerintah dalam bentuk pengelolaan secara bersama dimana masyarakat berpartisipasi aktif baik dalam perencanaan sampai pada pelaksanaannya [12,13]. Pemikiran ini sangat didukung oleh tujuan jangka panjang pembangunan wilayah pesisir di Indonesia antara lain:

1) Peningkatan kesejahteraan masyarakat melalui perluasan lapangan kerja dan kesempatan usaha.

2) Pengembangan program dan kegiatan yang mengarah kepada peningkatan pemanfaatan secara optimal dan lestari sumber daya di wilayah pesisir dan lautan.

3) Peningkatan kemampuan peran serta masyarakat pantai dalam pelestarian lingkungan.

4) Peningkatan pendidikan, latihan, riset dan pengembangan di wilayah pesisir dan lautan.

Dari beberapa tujuan tersebut di atas maka pemanfaatan secara optimal dan lestari adalah salah satu yang menjadi pertimbangan utama di dalam pengelolaan sumber daya [14]. Pemanfaatan secara lestari hanya akan dicapai jika sumber daya dikelola secara baik, proporsional dan transparan [15]. Sumber daya yang di maksud adalah sumber daya manusia, alam, buatan dan sosial. Perlindungan dan Pengelolaan Lingkungan Hidup telah diatur dalam Undang-Undang No. 32 Tahun 2009, dimana masyarakat mempunyai kewajiban untuk menjaga dan mengelola serta melestariakan sumberdaya alam untuk keberlanjutan kehidupan masyarakat $[16,17,18]$. Dikaitkan dengan pengembangan dan pengelolaan wilayah pesisir di Indonesia di jabarkan dalam Undang-Undang No 27 Tahun 2007 yang diperbaharui dengan Undang-Undang No. 1 Tahun 2014 [19], mewajibkan bsetiap kegiatan di wilayah pesisir melibatkan peran serta masyarakat lokal $[20,21]$. Dengan demikian perlindungan dan pengelolaan lingkungan 


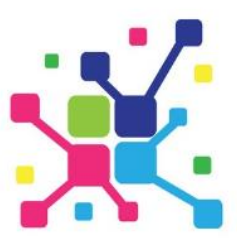

A J A D

Jurnal Pengabdian kepada Masyarakat

Vol. 1, No. 1, May, 2021, pp. 26-37

DOI : https://doi.org/10.35870/ajad.v1i1.5

hidup bukan hanya tanggung jawab dari pemerintah pusat tetapi kewenangan tersebut telah dilimpahkan kepada pemerintah daerah dengan dikeluarkannya UU No. 23 tahun 2014 yang tidak lagi memberikan kewenangan pada daerah Kota dan Kabupaten dalam mengelola pesisir dan lautnya yang sebelum berlakunya UU yang baru wilayah laut masih sejauh 12 mil untuk propinsi dan 1/3 untuk kabupaten [22,23].

Oleh karena itu pilihan otonomi merupakan suatu mekanisme yang ingin mendekatkan pemerintah dengan masyarakatnya [24,25]. Tujuannya adalah masyarakat dalam proses penyelenggaraan negara, politik, sosial, ekonomi, budaya serta penguasaan dan pengelolaan sumber daya pesisir dan laut yang seharusnya tidak perlu dijalankan sepenuhnya oleh negara [25]. Otonomi daerah di wilayah laut juga akan memiliki makna pembebasan dan pemberdayaan bagi masyarakat nelayan dan petani ikan serta perlindungan lingkungan alam di laut [26], jika masyarakat diberikan kembali haknya (re-entitle) dalam menguasai dan mengelolanya sumber daya sektor kelautan secara kolektif dan partisipatif [26,27]. Oleh karena itu, political will pemerintah adalah (1) bagaimana menfasilitasi proses peningkatan kapasitas masyarakat dalam mengelola dan memanfaatkan sumber daya kelautan secara kolektif dan berkelanjutan, (2) bagaimana melindungi masyarakat dan sumber daya sektor kelautan dari penetrasi kekuatan rent seeker yang semakin mudah menemukan jalannya ke daerah-daerah dengan perangkat institusional yang sudah mereka kuasai dengan paradigma otonomi daerah ala Orde Baru $[28,29]$.

Pembangunan berbasis lokal adalah bahwa pembangunan itu bukan saja dilakukan setempat tetapi juga melibatkan sumber daya lokal sehingga akhirnya return to local resource dapat dinikmati oleh masyarakat lokal [30,31,32]. Dengan demikian maka prinsip daya saing komparatif akan dilaksanakan sebagai dasar atau langkah awal untuk mencapai daya saing kompetitif [33,34]. Pembangunan berbasis lokal tidak membuat penduduk lokal sekedar penonton dan pemerhati di luar sistem, tetapi melibatkan mereka dalam pembangunan itu sendiri $[35,36]$.

Pembangunan yang berorientasi kesejahteraan menitikberatkan kesejahteraan masyarakat dan bukannya peningkatan produksi [37]. Ini merubah prinsip-prinsip yang dianut selama ini yaitu bahwa pencapaian pembangunan lebih diarahkan pemenuhan target-target variable ekonomi makro. Pembangunan komprehensif yang diwujudkan dalam bentuk usaha kemitraan yang mutualistis antara orang lokal (orang miskin) dengan orang yang lebih mampu. Kemitraan akan membuka akses orang miskin terhadap teknologi, pasar, pengetahuan, modal, manajemen yang lebih baik, serta pergaulan bisnis yang lebih luas [38,39].

Oleh karena itu tim memandang masih perlu dilakukan konsultasi hukum terhadap masyarakat khususnya masyarakat Kelurahan Batee Shok Kecamatan Sukakarya dipilih karena pertimbangan untuk mengkaji dan mengetajui serta mencari solusi mengenai masalah-masalah pengelolaan wilayah pesisir serta bagaimana peran 


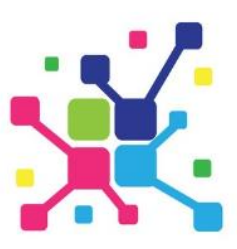

berbasis masyarakat dalam rangka menghadapi permasalah pesisir khususnya pemanfaatan ruang pesisir di Kota Sabang.

Kehidupan Masyarakat Mitra di Kelurahan Batee Shok, Juroeng Pria Laot Kecamatan Sukakarya, yang pemukiman di wilayah pesisir berdekatan dengan Kota Sabang, memberi dampak positif terhadap perkembangan perekonomian masyarakat kelurahan terutama pengaruh moderniasi. Laju tingkat pertumbuhan masyarakat dan pembangunan yang mengarah pada sector pariwisata membuat pergeseran paradigma masayrakat yang dahulu pada sector perikanan dan perkebunan, mengarah pada sector pariwisata khususnya wisata laut. Dampak positif dan negative yang kemungkinan timbul akibat pergeseran paradigma tersebut antara lain peralihan hak kepemilikan lahan kepada para pemilik modal dan pengaruh budaya asing yang kemungkin mempengaruhi budaya local diakibatkan pembangunan sector-sektor pariwisata seperti pusat penyelaman dan fasilitas penunjang lainnya seperti rumah makan dan perhotelan. Oleh karena itu sebagai upaya harmonisasi antara laju pertumbuhan pembangunan dan sector pariwisata, perlu di kaji dan memberikan advokasi serta konsultasi hukum sehubungan dengan peran masyarakat dalam pengelolaan pesisir berbasis masyarakat sehingga tidak menimbulkan resistensi terhadap kehidupan masyarakat.

Dampak pembangunan fisik di wilayah pesisir terutama dengan pengembangan reklamasi tahap kedua, memberikan dampak lingkungan terhapat pola ruang dan struktur ruang. Oleh karena itu perlu pemahaman masyarakat dalam mengantisipasi agar tidak terjadi benturan sosial dan kesenjangan akibat pelaksanaan pembangunan di kemudian hari. Potensi ekosistem laut yang masih baik, namun disisi lain mulai bergeser akibat laju pembangunan yang mengarah ke perusakan lingkungan hidup yang mengancam ekosistem pesisir seperti hutan mangrove, terumbu karang dan perikanan, termasuk lokasi pencaharian masyarakat nelayan. Oleh karena itu sebagai salah satu upaya kegiatan Iptek berbasis Masyarakat adalah memberikan pemahaman hukum lingkungan untuk kepatuhan bermasyarakat dalam penyelesaian masalah-masalah yang kemungkinan timbul dalam kegiatan pembangunan pesisir di Kelurahan Batee Shok Kecamatan Sukakarya.

Berdasarkan permasalahan Mitra maka Tim penyuluh menawarkan solusi dengan melakukan penerapan Ilmu Pengetahuan melalui program IPTEKS bagi masyarakat di Pusat Penelitian dan Pengabdian kepada Masyarakat STIES untuk melakukan advokasi dan konsultasi hukum kepada masyarakat di Kelurahan Batee Shok Juroeng Pria Laot Kecamatan Sukakarya Kota Sabang dalam rangka meminimalisasi konflik dan pemberian kewenangan masyarakat lokal dalam perlindungan dan pengelolaan lingkungan hidup khususnya pengelolaan sumberdaya wilayah pesisir.

Pelaksanaan kegiatan Iptek berbasis masyarakat antara lain program Penyuluhan dan Konsultasi Hukum dengan metode Focus Groups Discussion (FGD), kepada kelompok-kelompok masyarakat sasaran, yaitu kelompok perangkat kelurahan, 
kelompok masyarakat nelayan dan masyarakat petani serta kelompok masyarakat pengusaha.

Pelaksanaan dilakukan dengan beberapa kali pertemuan, dan kemudian menjaring masyarakat yang dianggap mempunyai kesanggupan dalam memimpin kelompok serta dapat bertanggung jawab dalam kegiatan yang ditindak lanjuti setelah berakhirnya kegiatan Iptek berbasis masyarakat. Sasaran dari kegiatan ini adalah restrukturisasi kelompok masyarakat yang sadar hukum dengan memilih serta menentukan sendiri wilayah pesisir untuk dijadikan sebagai kawasan yang dilindungi, sebagai bagian dari kepedulian masyarakat terhadap pelestarian sumberdaya pesisir dalam pengelolaan yang terpadu antara pemerintah masyarakat serta pengusaha

Solusi penyelesaian masalah di pesisir Kecamatan Sukakarya dan Model Pengelolaan Pesisir Berbasis Masyarayakat serta Rekonstruksi Penguatan Kelompok Pengelola Masyarakat Pengelola Pesisir. Target yang menjadi sasaran dalam Program IbM di Kelurahan Batee Shok Kecamatan Sukakarya di Juroeng Pria Laot, menitik beratkan pada dampak abrasi, sedimentasi pendangkalan dan penebangan hutan mangrove. Dengan tindakan penyuluhan Hukum telah memberikan pemahaman kepada masyarakat Juroeng Pria Laot, untuk turut serta berpartisipasi secara aktif dalam penangulangan abrasi, serta sedimentasi dan pelesarian hutan mangrov. Dari ketiga permasalahan yang nyata telah diantisipasi dengan program penanaman mangrove pada lokasi-lokasi yang akan ditentukan kemudian, dengan bekerjasama dengan lembaga terkait yang mengelola hutan di Kota Sabang.

Model Pengelolaan Pesisir Berbasis Masyarakat, telah di lakukan pendidikan lingkungan hidup kepada masyarakat setempat dan khususnya di Juroeng Pria Laot akan membentuk kembali Badan Pengelola Daerah Mangrove sebagai Kelompok Pengelola di bawah asuhan Balai Konservasi Sumberdaya Alam dan Badan Pengelola Sukakarya. Hal ini diinisiasi kerjasama karena Juroeng Pria Laot menjadi daerah kelurahan yang memiliki lokasi strategis dalam pengembangan wisata bahari berdasarkan lokasi yang berjarak sangat dekat apabila akan menuju ke Pulau Weh dan sekitarnya.

Sebagai bagian dari pengembangan wisata bahari, telah dibangun jembatan ke arah laut untuk mempermudah akses dari dan ke Perencanaan Taman Nasional. Beberapa hal yang menjadi target dan luaran dapat dilakukan dalam membangun kesadaran masyarakat dengan kegiatan antara lain:

1) Diskusi bersama masyarakat untuk memahami kondisi pantai saat ini dan sebelumnya.

2) Mengidentifikasi dan menyadari bersama dampak hilang/rusaknya hutan mangrove.

3) Menentukan dan menyepakati bersama solusi mengatasi masalah akibat hilang/rusaknya hutan mangrove.

4) Sosialisasi peraturan-peraturan yang berlaku tentang hutan mangrove. 
5) Memperluas wawasan tentang manfaat hutan mangrove, perencanaan dan pelaksanaan bersama penanaman mangrove, serta pembentukan kelompok masyarakat pengelola pesisir dan pelestari hutan mangrove

\section{Metode}

a. Metode Pelaksanaan Kegiatan

Metode yang digunakan dalam kegiatan IbM di Kelurahan Batee Shok Kecamatan Sukakarya, di Juroeng Pria Laot, dengan pendekatan sosial, yaitu menghubungi masyarakat dan kelompok kemudian dilaksanakan pertemuan masyarakat dan Tim dengan metode umpan-balik menggali informasi permasalah serta strategi dan tindakan yang pernah dilakukan. Selanjutnya melaksanakan Penyuluhan Hukum dan Strategi Program bagi Kelompok Masyarakat Pengelola Pesisir Hutan Mangrove. Kegiatan dilakukan dengan Focus Group Discussion (FGD), untuk mendapatkan solusi bersama penanggulangan perusakan lingkungan pesisir. Peserta terdiri Kelompok Masyarakat Pengelola dan Masyarakat simpatisan. Pelaksanaan melibatkan mahasiswa sebagai bagian pembelajaran dalam cara dan proses penyelesaian sengketa lingkungan yang terkait dengan Mata Pelajaran Hukum Lingkungan dan Ekonomi Manajemen.

b. Waktu Efektif Pelaksanaan Kegiatan

Kegiatan Pelaksanaan Pengabdian Kepada Masyarakat ini dilakukan selama 1(satu) bulan pada bulan Agustus tahun 2015.

\section{c. Tempat Kegiatan}

Lokasi pengabdian ini pada daerah Desa Pria Laot Kecamatan Sukakarya Kota Sabang. Gampong ini terletak di teluk Sabang. Berada di sekitar laut dan gunung. Kelompok sasaran pengabdian ini adalah; 1) Anggota Kelompok Petani, dan 2) Anggota Kelompok Nelayan Desa Pria Laot. Jumlah peserta dalam pelatihan ini berjumlah 20 orang. Peserta pelatihan diharapkan berasal dari kalangan Kelompok Tani dan Nelayan Desa Pria Laot.

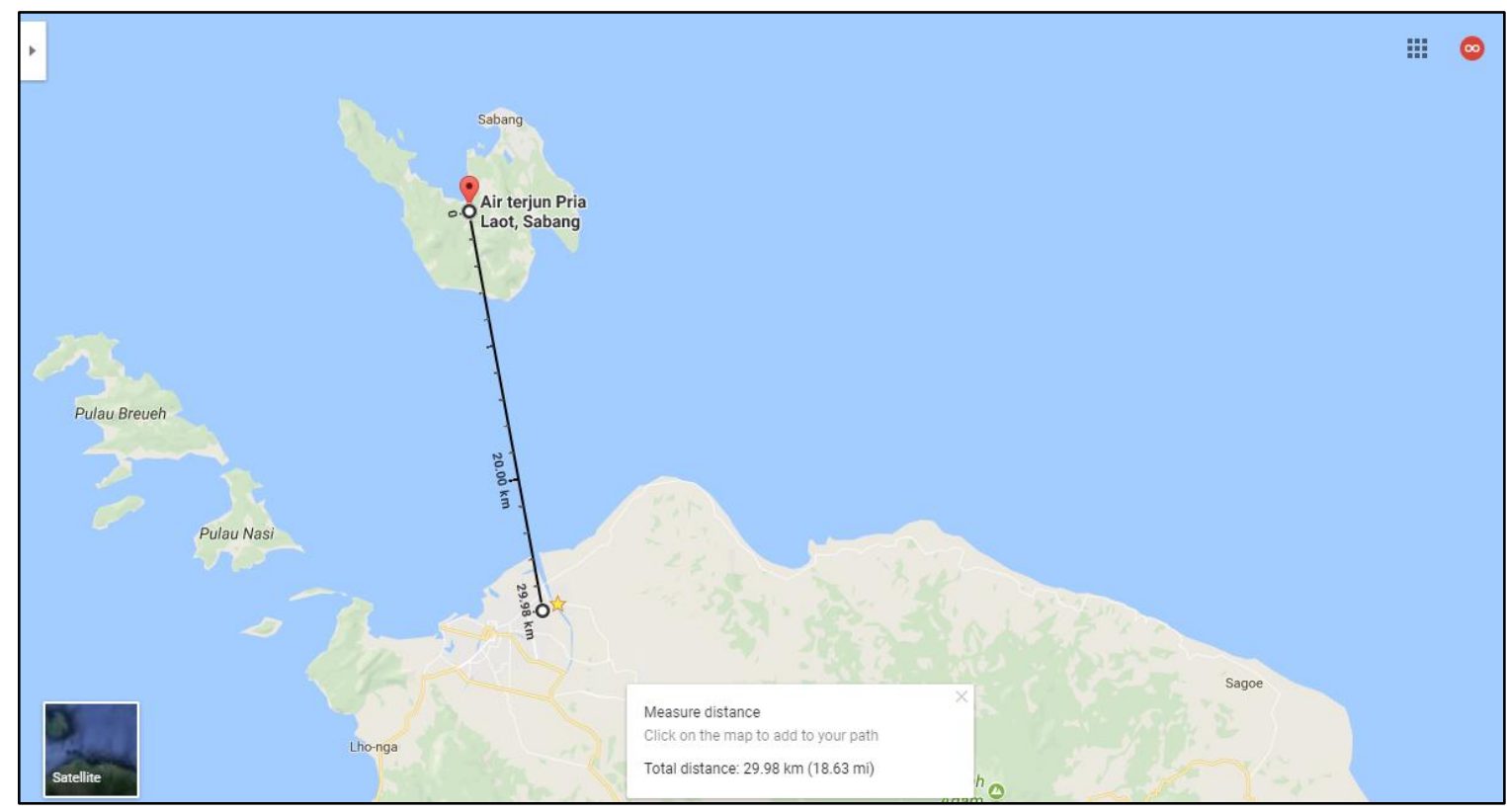

Gambar 1. Map Lokasi Kegiatan 


\section{Hasil}

a. Materi Sosialisasi

Target yang menjadi sasaran dalam Program IbM di Kelurahan Batee Shok Kecamatan Sukakarya di Juroeng Pria Laot, menitik beratkan pada dampak abrasi, sedimentasi pendangkalan dan penebangan hutan mangrove. Dengan tindakan penyuluhan Hukum telah memberikan pemahaman kepada masyarakat Juroeng Pria Laot, untuk turut serta berpartisipasi secara aktif dalam penangulangan abrasi, serta sedimentasi dan pelesarian hutan mangrov. Dari ketiga permasalahan yang nyata telah diantisipasi dengan program penanaman mangrove pada lokasi-lokasi yang akan ditentukan kemudian, dengan bekerjasama dengan lembaga terkait yang mengelola Kawasan Taman Nasional Kota Sabang.

Model Pengelolaan Pesisir Berbasis Masyarakat, telah di lakukan pendidikan lingkungan hidup kepada masyarakat setempat dan khususnya di Juroeng Pria Laot akan membentuk kembali Badan Pengelola Daerah Mangrove sebagai Kelompok Pengelola di bawah asuhan Balai Konservasi Sumberdaya Alam dan Badan Pengelola Kota Sabang. Hal ini diinisiasi kerjasama karena Juroeng Pria Laot menjadi daerah kelurahan yang memiliki lokasi strategis dalam pengembangan wisata bahari berdasarkan lokasi yang berjarak sangat dekat apabila akan menuju ke Pulau Weh dan sekitarnya.

Berbagai peraturan pemerintah yung berkaitan dengan pengelolaan hutan mangrove di Indonesia telah digulirkan dengan berbagai macam kebijakannya, namun yang terpenting diantaranya adalah :

a. Kebijakan nasional dibidang pengelolaan keanekaragaman hayati laut.

b. Strategi nasional dibidang pengelolaan mangrove.

c. Kebijakan nasional dibidang pembangunan

d. Strategi nasional dibidang pengelolaan jalur hijau pesisir.

Selain itu strategi pokok konservasi untuk mendasari pengelolaan hutan di kawasan pesisir, adalah sebagai berikut:

a. Perlindunga proses ekologis dan penyangga kehidupan kawasan.

b. Pengawetan keragaman sumber daya plasma nuflah.

c. Pelestarian pemanfaatan jenis dan ekosistem.

d. Tata guna dan tata ruang kawasan hutan pantai.

Pada dasarnya kebijakan-kebijakan tersebut memberikan suatu batasan yang sangat jelas, namun dalam pelaksanaan penghijauan harus menyertakan masyarakat setempat. Untuk mendukung keberhasilan program rehabilitasi dan konservasi hutan mangrove tersebut, maka seyogyanya instansi pemerintah setempat dan LSM dilibatkan untuk mengkoordinasi program, memonitor pelaksanaan program serta 


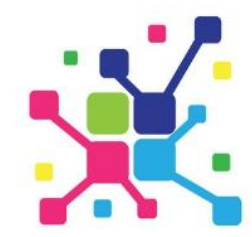

A J A D

Jurnal Pengabdian kepada Masyarakat

Vol. 1, No. 1, May, 2021, pp. 26-37

DOI : https://doi.org/10.35870/ajad.v1i1.5

bertanggung jawab untuk memberikan penyuluhan tentang arti penting dari program yang dilakukan.

Upaya-upaya yang dapat dilakukan untuk memperbaiki dan melestarikan hutan mangrove antara lain:

a. Penanaman kembali mangrove sebaiknya melibatkan masyarakat. Modelnya dapat masyarakat terlibat dalam pembibitan, penanaman dan pemeliharaan serta pemanfaatan hutan mangrove berbasis konservasi. Model ini memberikan keuntungan kepada masyarakat antara lain terbukanya peluang kerja sehingga terjadi peningkatan pendapatan masyarakat.

b. Pengaturan kembali tata ruang wilayah pesisir: pemukiman, vegetasi, dll. Wilayah pantai dapat diatur menjadi kota ekologi sekaligus dapat dimanfaatkan sebagai wisata pantai (ekoturisme) berupa wisata alam atau bentuk lainnya.

c. Peningkatan motivasi dan kesadaran masyarakat untuk menjaga dan memanfaatkan mangrove secara bertanggungjawab.

d. Ijin usaha dan lainnya hendaknya memperhatikan aspek konservasi.

e. Peningkatan pengetahuan dan penerapan kearifan local tentang konservasi

f. Peningkatan pendapatan masyarakat pesisir

g. Program komunikasi konservasi hutan mangrove

h. Penegakan hukum

i. Perbaikkan ekosistem wilayah pesisir secara terpadu dan berbasis masyarakat. Artinya dalam memperbaiki ekosistem wilayah pesisir masyarakat sangat penting dilibatkan yang kemudian dapat meningkatkan kesejahteraan masyarakat pesisir. Selain itu juga mengandung pengertian bahwa konsepkonsep lokal (kearifan lokal) tentang ekosistem dan pelestariannya perlu ditumbuh-kembangkan kembali sejauh dapat mendukung program konservasi.
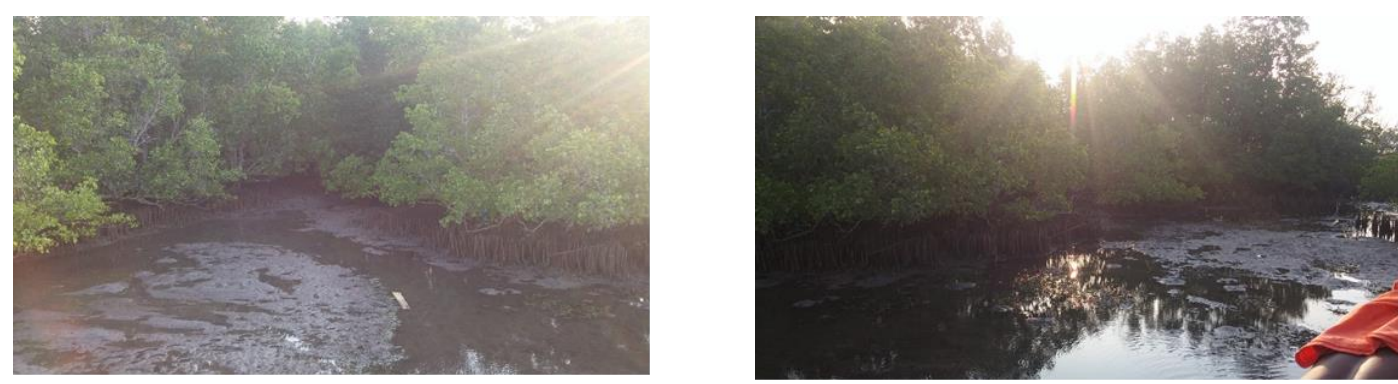

Gambar 2. Dokumentasi Kegiatan Hutan Program Konservasi

b. Profil Masyarakat Sasaran

Gampong Pria Laot merupakan Kelurahan Batee Shok, Kecamatan Sukakarya, Kotamadya Sabang. Gampong ini terletak di teluk Sabang. Berada di sekitar laut dan gunung. Adapun luas Kelurahan Batee Shok \pm 123 hektar, yang terdiri dari 
perumahan warga dan perkebunan warga, yang berbatasan dengan; Sebelah Barat berbatasan dengan Iboih, Sebelah Timur berbatasan dengan Paya Seunara, Sebelah Utara berbatasan dengan Paya Keunekai, dan Sebelah Selatan berbatasan dengan Paya.

Jumlah penduduk di Kelurahan Batee Shok termasuk banyak bila dibandingkan dengan gampong lainnya di kecamatan Sukakarya. Jumlah keluarga di Kelurahan Batee Shok adalah 337 KK, dengan jumlah masyarakat sebanyak 1383 jiwa. Penduduknya banyak yang bermata pencaharian sebagai petani (berkebun) dan nelayan. Kondisi tanah yang subur dimanfaatkan warga setempat untuk menanam pala, pinang, sawi, pisang, dan beberapa tanamannya lainnya. Demikian pula warga yang rumahnya dekat dengan laut banyak membudidayakan ikan yang nantinya di jual ke pasar-pasar yang ada di Sabang. Kelurahan Batee Shok memiliki empat meunasah yang terbagi di empat jurong yang ada di gampong tersebut. Meunasah biasanya digunakan masyarakat untuk kegiatan keagamaan seperti beribadah, pengajian dan sebagainya. Meunasah juga biasa digunakan sebagai tempat bermusyawarah dan mufakat antar warga gampong tersebut, serta digunakan pula dalam acara kegiatan PKK. Kelurahan Batee Shok juga memiliki sebuah puskesmas untuk menunjang kesehatan warga. Puskesmas ini terletak di Jurong Pria Laot. Kelurahan Batee Shok juga memiliki potensi wisata air terjun dan fasilitas hiburan yaitu "Water Boom".

Untuk akses yang digunakan dalam perjalan menuju Kelurahan Batee Shok dapat ditempuh melalui jalan utama yang sudah di aspal, yakni melewati perumahan warga dan juga pegunungan. Sistem pemerintahan Kelurahan Batee Shok dipimpin oleh seorang Keuchik, Imam Mukim, serta Tuha Peut yang mempunyai peranan cukup kuat dalam tatanan pemerintahan gampong yakni sebagai penasehat, baik dalam penetapan sebuah kebijakan ditingkat pemerintahan gampong maupun dalam memutuskan sebuah putusan hukum adat. Masyarakat di gampong ini sangat menjunjung tinggi agama dan adat budaya setempat (BPS, 2016).

\section{Kesimpulan}

Adapun kesimpulan dari kegiatan pengabdian sebagai berikut:

1) Terbentuknya kesadaran Hukum Lingkungan bagi masyarakat pesisir untuk menjaga dan melindungi sumberdaya pesisir di daerah pemukiman masyarakat.

2) Terbentuk dan tertata kembali Kelompok Masyarakat Pengelola Pesisir.

3) Membuka akses bagi masyarakat di luar Kelurahan Batee Shok untuk memanfaatkan sarana dan prasarana yang menunjang rencana dan program Pariwisata Taman Nasional Kota Sabang. 


\section{Daftar Referensi}

[1] Efendy, M., 2009. Pengelolaan Wilayah Pesisir Secara Terpadu: Solusi Pemanfaatan Ruang, Pemanfaatan Sumberdaya Dan Pemanfaatan Kapasitas Asimilasi Wilayah Pesisir Yang Optimal Dan Berkelanjutan. Jurnal Kelautan: Indonesian Journal of Marine Science and Technology, 2(1), pp.81-86.

[2] Patuwo, N.C., Pelle, W.E., Manengkey, H.W., Schaduw, J.N., Manembu, I. and Ngangi, E.L., 2020. KARAKTERISTIK SAMPAH LAUT DI PANTAI TUMPAAN DESA TATELI DUA KECAMATAN MANDOLANG KABUPATEN MINAHASA. JURNAL PESISIR DAN LAUT TROPIS, 8(1), pp.70-83.

[3] ROSSANTY, E., 2008. DAMPAK REKLAMASI PANTAI MARINA KOTA SEMARANG (Doctoral dissertation, Universitas Diponegoro).

[4] Paramasatya, A., 2015. Pemetaan Potensi Sumberdaya Pesisir Di Kelurahan Mayangan Kecamatan Mayangan Kota Probolinggo Provinsi Jawa Timur (Doctoral dissertation, Universitas Brawijaya).

[5] Wahyudi, A., 2015. Pemetaan Potensi Sumberdaya Pesisir Di Kelurahan Ketapang Kecamatan Kademangan Kota Probolinggo Propinsi Jawa Timur (Doctoral dissertation, Universitas Brawijaya).

[6] Radhiallah, P., 2018. Studi Potensi Sumber Daya Alam dan Permasalahan Wilayah Pesisir di Desa Kuala LangsaKecamatan Langsa Barat Kota Langsa. Jurnal Samudra Geografi, 1(1), pp.1-6.

[7] Gumelar, I. and Ruswandi, A., 2017. Valuasi Ekonomi Kekayaan Sumberdaya Kelautan Jawa Barat Selatan. Creative Research Journal, 1(01), pp.1-15.

[8] Firdaus, F., Trisutomo, S. and Ali, M., 2018. PENGEMBANGAN PULAU-PULAU KECIL BERBASIS INFRASTRUKTUR DAN SOSIAL EKONOMI MASYARAKAT YANG BERKELANJUTAN. PROSIDING SEMNASTEK 2018, 1(1).

[9] Kadarisman, M., 2017. Kebijakan keselamatan dan keamanan maritim dalam menunjang sistem transportasi laut.Jurnal Manajemen Transportasi \& Logistik, 4(2), pp.177-192.

[10] Fithria, D. and Agustiar, A., 2015. Peran pemerintah dan partisipasi masyarakat dalam konservasi wilayah pesisir di Kabupaten Aceh Barat dan Kabupaten Aceh Jaya. Acta Aquatica: Aquatic Sciences Journal, 2(1), pp.55-59.

[11] Subagiyo, A., Wijayanti, W.P. and Zakiyah, D.M., 2017. Pengelolaan wilayah pesisir dan pulau-pulau kecil. Universitas Brawijaya Press. 


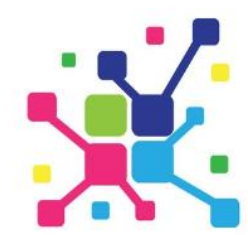

A J A D

Jurnal Pengabdian kepada Masyarakat

Vol. 1, No. 1, May, 2021, pp. 26-37

DOI : https://doi.org/10.35870/ajad.v1i1.5

[12] Husamah, H. and Hudha, A.M., 2018. Evaluasi implementasi prinsip ekowisata berbasis masyarakat dalam pengelolaan clungup mangrove conservation Sumbermanjing Wetan, Malang. Jurnal Pengelolaan Sumberdaya Alam dan Lingkungan, 8(1), pp.86-95.

[13] Prihanta, W., Zainuri, A.M., Hartini, R., Syarifuddin, A. and Patma, T.S., 2020. Pantai Taman-Pacitan ecotourism development: Conservation and community empowerment orientation. Journal of Community Service and Empowerment, 1(1), pp.1-16.

[14] Nawawi, Z.H., Alamsyah, A. and Hasan, I., 2018. PERAN PEMERINTAH DALAM PENGELOLAAN MANGROVE (Studi Terhadap Pengelolaan Mangrove di Lantebung). Sulesana: Jurnal Wawasan Keislaman, 11(2).

[15] Lestari, N.A. and Rustiana, S.H., 2019. PENGARUH PERSEPSI OWNER DAN PENGETAHUAN AKUNTANSI DALAM PENGGUNAAN SISTEM INFORMASI AKUNTANSI TERHADAP KINERJA USAHA MIKRO, KECIL, DAN MENENGAH DI PAMULANG. BASKARA: Journal of Business and Entrepreneurship, 1(2), pp.67-80.

[16] Niman, E.M., 2019. Kearifan lokal dan upaya pelestarian lingkungan alam. Jurnal Pendidikan dan Kebudayaan MISSIO, 11(1), pp.91-106.

[17] AGUSTRIA, A.Y., 2020. IMPLEMENTASI UNDANG-UNDANG NOMOR 32 TAHUN 2009 TENTANG PERLINDUNGAN DAN PENGELOLAAN LINGKUNGAN HIDUP DALAM PERSPEKTIF SIYĀSAH SYA'IYYAH (Studi di Desa Pulau Negara, Kecamatan Buay Pemuka Peliung, Kabupaten Oku Timur, Sumatera Selatan) (Doctoral dissertation, UIN Raden Intan Lampung).

[18] Noor, F., 2018. Pengelolaan Sumber Daya Alam Berdasar Prinsip Fiqh AlBi'ah. Jurnal Ilmiah Pendidikan Pancasila dan Kewarganegaraan, 3(1), pp.47-55.

[19] Datau, R. and Hairan, H., 2019. Aspek Hukum Dalam Pengelolaan Wilayah Pesisir Dalam Perspektif Otonomi Daerah. Gorontalo Law Review, 2(2), pp.81-94.

[20] Ruslan Renggong, S.H., 2018. Hukum Pidana Lingkungan. Kencana.

[21] Hadi, S., Syahrudin, S. and Kusumawardani, R., 2019, February. METADATA UNTUK PEMANFAATAN DATA DAN INFORMASI GEOSPASIAL Kepastian Dalam Penyusunan Perencanaan Tata Ruang. In Seminar Nasional Geomatika (Vol. 3, pp. 725-734).

[22] Syahuri, T. and Sitompul, E.O., 2020. ANALISIS YURIDIS PENGELOLAAN BATAS WILAYAH LAUT DAN PESISIR BERDASARKAN UNDANG-UNDANG NOMOR 23 TAHUN 2014 TENTANG PEMERINTAHAN DAERAH. Esensi Hukum, 2(2), pp.13-22. 


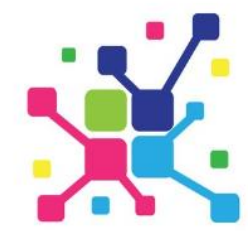

A J A D

Jurnal Pengabdian kepada Masyarakat

Vol. 1, No. 1, May, 2021, pp. 26-37

DOI : https://doi.org/10.35870/ajad.v1i1.5

[23] Aspan, Z., Arifin, A., Ilyas, A. and Yunus, A., 2019. Perizinan Pengelolaan Wilayah Pesisir sebagai Kewenangan yang Diderivasi dari Hak Menguasai Negara. Al-Azhar Islamic Law Review, 1(1), pp.9-25.

[24] Karo-Karo, R. and IP, M., 2019. PERANAN PEMERINTAHAN DAERAH DALAM PELAYANAN PUBLIK. Jurnal Ilmiah" INTEGRITAS" Vol, 4(1).

[25] Setiawan, W.D., 2020. Reformasi Birokrasi dan Otonomi Daerah. Jurnal Wacana Kinerja: Kajian Praktis-Akademis Kinerja dan Administrasi Pelayanan Publik, 10(4), pp.71-78.

[26] Choironi, R., 2018. Pemberdayaan masyarakat berbasis potensi lokal melalui pengolahan limbah cangkang kerang di PKBM Kridatama Desa Sendang Sikucing Kecamatan Rowosari Kabupaten Kendal (Doctoral dissertation, UIN Walisongo).

[27] Rukin, S.P., 2019. Pembangunan Perekonomian Masyarakat Desa Mandiri. Zifatama Jawara.

[28] Prayitno, G. and Subagiyo, A., 2018. Membangun Desa: Merencanakan Desa dengan Pendekatan Partisipatif dan Berkelanjutan. Universitas Brawijaya Press.

[29] Apriliani, T., Kurniasari, N. and Yuliati, C., 2019. Strategi pengelolaan perikanan di waduk sempor, kabupaten kebumen, provinsi jawa tengah. Jurnal Sosial Ekonomi Kelautan dan Perikanan, 13(2), pp.153-166.

[30] Syarifah, L., 2018. Strategi Percepatan Pembangunan Daerah Berbasis Kearifan Lokal di Kecamatan Gunung Wungkal. Religi: Jurnal Studi Agama-agama, 14(1), pp.135-153.

[31] Idawati, I., Yuliana, Y., Rosalinda, M. and Kartini, K., 2020. Penyuluhan Kesehatan Tentang Pentingnya Program Keluarga Berencana di Desa Balee Ujong Rimba Kecamatan Mutiara Timur Kabupaten Pidie. Jurnal Pengabdian Nasional (JPN) Indonesia, 1(2), pp.56-62.

[32] Salam, A. and Iqbal, T., 2020. IbM Pelatihan Microsoft Office Dalam Rangka Membentuk Masyarakat Yang Profesional.Jurnal Pengabdian Nasional (JPN) Indonesia, 1(1), pp.10-15.

[33] Ahmad, L., Wali, M., Akbar, R. and Syafwandhinata, J., 2020. IbM Pemberdayaan Generasi Muda melalui Enterpreneurship. Jurnal Pengabdian Nasional (JPN) Indonesia, 1(1), pp.30-36.

[34] Halfira Agustia, E., Yudhi Prastya, I. and Prima Safitri, D., Dinamika Pemberdayaan Ekonomi dan Lingkungan Melalui Bank Sampah (Studi Pada Bank Sampah Tokojo). DINAMIKA PEMBERDAYAAN EKONOMI DAN LINGKUNGAN MELALUI BANK SAMPAH (STUDI PADA BANK SAMPAH TOKOJO). 
[35] Adiwaty, M.R., Pertiwi, T.K. and Fitriyah, Z., 2019. PEMBERDAYAAN PEREMPUAN PESISIR BERBASIS POTENSI LOKAL DAN PENDIDIKAN LIFE SKILL DI KABUPATEN SIDOARJO. Dinamika Administrasi: Jurnal Ilmu Administrasi dan Manajemen, 2(2).

[36] Khusna, A.M., 2019. Pengembangan masyarakat berbasis potensi lokal: studi pada Kampung Tematik Jamu Kelurahan Wonolopo Kecamatan Mijen Kota Semarang (Doctoral dissertation, UIN Walisongo Semarang).

[37] Malik, H., 2019. Bangun Industri Desa Selamatkan Bangsa: Strategi Pembangunan Industri Desa di Kabupaten Kaur, Bengkulu. PT Penerbit IPB Press.

[38] Khairul, A.M.R.I., 2018. The macroeconomic impact of regional minimum wages: A cross-province data evidence from Indonesia. Regional Science Inquiry, 10(3), pp.163-176.

[39] Rizal, S., 2020. PKM: Pemberdayaan Generasi Muda Melalui Enterpreneurship di Gampong Leuge Kecamatan Peureulak Kabupaten Aceh Timur: Pemberdayaan Generasi Muda Melalui Enterpreneurship di Gampong Leuge Kecamatan Peureulak Kabupaten Aceh Timur. TRIDARMA: Pengabdian Kepada Masyarakat (PkM), 3(1, Mei), pp.35-39. 